\title{
THE ANAESTHETIST AND PULMONARY TUBERCULOSIS
}

\section{J. P DechêNe, M.D., and Fernando Hudon, M.D., F.R.C.P.(c), F.F.A.R.C.s. *}

IN this paper, we are going to describe the organization of an Anaesthesiologic Department in a modern sanatorium where major chest surgery is done for tuberculosis patients, the description will include the role played by the anaesthetsst during the pre- per- and post-operative periods.

\section{The Preoperative Period}

As many of them represent poor anaesthetic risks, the importance of a very attentive preparation on these pulmonary cases will be realized We routinely request the following exammations:

1. Clinical findings and physical exammation.

2. Laboratory examinations.

3. X-ray.

4. Some cardio-pulmonary function test:

(a) Vital capacity

(b) Tumed vital capacity

(c) Maximum breathing capacity

(d) Ventilation equivalent

(e) Minute volume

(f) Blood gas analysis

(g) Venous pressure

(h) Circulation time

(i) E.K.G.

From the results of these examinations, the anaesthetist may arrange a better preparation for the patient, for whom the following things are carried out by the anaesthetist or a qualified person:

1. Restoration of fluid balance (Fluid and blood transfusion).

2. Aerosol therapy (Streptomycin and Vaponefrin).

3. Postural drainage.

4. Physiotherapy.

5. Preoperative sedation.

Our patients under treatment with isonicotinic acid derivatives, especially the isopropyl derivative (Marsilid ${ }^{1}$ ), have shown oxygenation problems and convulsions at the anaesthetic period. We now routinely stop this medication one month before the operation in order to avoid such complications.

\section{The Preoperative Period}

With the best anaesthetic technique, these patients present many problems:

1. Reduction of static lung volume

(a) Reduction of usab_e vital capacity

-Laval Hospital, Sannte-Foy, Quebec, and Department of Anaesthesia, Laval University.

-Proprnetary name: Hoffmann-La Roche. 
(b) Increase of residual capacity

(c) Increase of functional residual air.

2. Inadequate dynamic lung volume

(a) Reduction of tidal air

(b) Reduction of maximum capacity

(c) Inadequate minute volume

(d) Abnormal ventilation equivalent.

3 Paradoxical respiration.

4. Mediastinal flutter.

5. Lessening of cardiac output and blood volume.

6. Delay in the venous return.

7 Hypoxemia or anoxemia.

8. Arterial-venous shunt.

9 Reflex problems.

10 Aspiration of secretions and spread of disease problems.

As the thoracic operation is taking place in the cardio-pulmonary area, which is one of the most reflexogenic zones of the body, both the surgical stimulus and the anaesthetic agents are prone to cause hypotension, bradycardia, arrhythmia, or even cardiac arrest.

As a preventive it might be well to mention preoperative topical anaesthesia of the whole tracheo-bronchial tree, intercostal nerve blocks, a good plane of general anaesthesia, good oxygenation of the patient, and sometimes an intravenous injection of a ganglioplegic drug.

Pulmonary tuberculosis patients frequently show a reduction of blood volume and anaemia. Replacement therapy with blood, plasma, or plasma expanders and electrolytes is imperative in order to avold shock and anoxemia.

Paradoxical respiration and mediastinal flutter are also serious problems, they can be minimized by intubation techniques, controlled or assisted respiration, and the face down position (Overholt).

Anaesthetic agents are a matter of choice At Laval Hospital, we use intravenous anaesthetic agents, curares combmed with nitrous-oxide Oxygen technique. For one reason or another, after a satisfactory understanding with the surgeons, cyclopropane or ether techniques are also used for some special cases.

Recently, for poor-risk patients, we tried a new technique of sedation of the autonomic nervous system devised in France by Huguenard and Laborit with "Cocktallytıque". Demerol, Diparcol, Phenergan, Largactl, associated or not with local or regional anaesthesia.

For intubation, encobronchial anaesthesia with Carlen's tube is our first choice, the advantages of th.s technique have been summarized as follows, by Dr. Carlens in Anesthesiology, January 1953 issue:

1 Once the chest is open, the diseased lung may be deflated to provide greater operating space when the lung is separated from the chest wall.

2. The lung can be inflated when lobar or intersegmental planes are developed.

3. The bronchus can be divided, whenever this is suitable during the resection and left open unthl it is convenient to close it. During the time the bronchus is 
open, a small plastic catheter is left in place for continuous suction, with suction close to the opening of the bronchus to collect blood and secretions.

4. It is not necessary to apply a clamp on the proximal part of the bronchus, thus injury to the bronchial wall is avoided.

5 . The bronchial tree may be inspected and aspirated by a small rubber catheter through the open bronchus.

6. Bronchotomies and resection of the carina and of the tracheal wall are facilitated by the method of endobronchial anaesthesia.

7. In wet cases during repeated aspirations one lun $\xi$ is always ventilated and the same plane of anaesthesia can be maintainer more easily. In some pneumonectomy cases with empyema we use endotracheal or endobronchial tubes along with the Thompson's blocker.

Before the time of Thompson's blocker and Ciarlens' catheter we had to rely on simple intubation with endotracheal or enclobronchial tubes. However, in children's surgery, the tracheo-bronchial tree does not allow any other technique and we still use these simple intubations.

Last year, Dr. Carlens paid a visit to our hospital and told us that five thousand cases were done in Sweden with his catheter with many advantages and without any harmful incident.

Up to now, at Laval Hospital, this technique of bronchial anaesthesia (Carlens' tube) has been used in more than five hundred cases: pulmonary resections, decortications, thoracoplasties. We tend to agree with Dr. Carlens' 1emarks. This tube is also used at our hospital for bronchospirometry. Its introduction is relatively smooth. Nevertheless a previous bronchoscopic examination is helpful.

The functions of an anaesthetist are not limited to the choice of good anaesthetic agents. He must also pay a close attention to the heart action and to the arterial oxygen saturation In this the cardiothacoscope and the oximeter may prove to be of great help.

If a cardiac arrest occurs, the anaesthetist should immediately look for close co-operation between the members of the surgical team. Without delay the surgeon performs cardiac massage for adequate circulation. The anaesthetist, on the other hand, administers oxygen under positive pressure. Everyone knows that thoracic surgery often means large amounts of blood lost. This may be immediately estimated by the weighing of the sponges and later on the postoperative ward, by blood volume dye test method. Then the blood volume is maintained at normal level by adequate replacement of blood loss.

\section{The Postoperative Period}

For the anaesthetist, the recovery period is as important as the operative one. During the first postoperative hours, the anaesthetıst stands by the patient as long as he needs his services. In the following days, in co-operation with the surgeon, the anaesthetist supervises oxygenation, blood transfusion, fluid balance, sedation, aerosol therapy and physiotherapy The pulse rate serves as a barem for oxygenation, a pulse of one hundred or over per minute is an indication for extending the oxygenation for two hours. The Anaesthesiologic 
Department, in our hospital, is also responsible for the Blood Transfusion Service. About one hundred transfusions monthly are given on active surgical wards.

According to fluid balance, the anaesthetist orders fluids and electrolyte solutions.

We routinely try to use less depressive sedatives (Demerol, Levodromoran), mfiltration blocks with cyclaine or xylocaine, 5 per cent alcohol solution given intravenously. Accordıng to Dr. Mary Knapp of Wesley Memorial, Chica jo, 5 per cent alcohol solution given intravenously increases the caloric intake, as a special value for patients with inanition, and reduces by 30 to 50 per cent the need of narcotics postoperatively.

The most serious respiratory complication, atelectasis, is jugulated by carbon dioxide mhalation in association with the physiotherapy practised in the immediate postoperative period, aerosol therapy (Streptomycin, Vaponefrin, Alevaure) and bronchial tollet by aspiration or broncho-aspiration are also helpful. But the use of some anaesthetic techniques has greatly reduced the postoperatıve respiratory complications for our patients.

As everyone knows, the anaesthetısts work more often in the Surgical Departinent than in the Medical Department, however, our services are also required by latter department to dispense to their patients the same services: oxygenttion, blood transfusion, aerosol therapy, nerve blocks, reanimation and also appreciation of anaesthetc risk

In conclusion, we may say that the recent advances in thoracic anaesthesia have greatly enlarged the thoracic surgical Field.

\section{RÉSUMÉ}

Au cours de ce travall, nous allons démontrer le rôle joué par l'anesthésiste dans un centre de chrurgie thoracique en tuberculose.

I A la période pré-opératone, l'anesthésiste se doit de bien connaître son patient afin d'être en mesure de le bien préparer à l'intervention. Il doit s'intéresser surtout à l'examen clınıque pré-opératorre et aux examens de la fonction cardıo-respiratoire. Survant les renseignements que lui ont fournis ces examens, it doit:

(a) restaurer l'équilibre électrolytique et surtout le volume sanguin;

(b) instıtuer de l'aérosolthérapie si nécessaire,

(c) diriger le physiotherapeute;

(d) décider de la technique anesthésique à employer,

(e) ordonner la prémédication la veille de l'opération.

En tuberculose pulmonaire, les problèmes communs a la chirurgie thoracique ne font que s'aggraver.

II. A la période opératorre, une bonne oxygénation est de rigueur, peu importe l'agent anesthésıque employé. A l'ouverture de la paroi, l'infiltration intercostale est farte pour prévenir certains réflexes vagaux et la respiration contrôlée ou assistée est pratiquée pour lutter contre la respiration paradoxale et le ballottement médiastinal.

Dans nos milieux, à cause de l'usage courant de l'électro-cautère, nous utilisons 
la technique Protoxyde d'azote oxygène avec emploi de substances intra-veineuses : anesthésiques, sédatifs et curarisants. Pour les raisons mentionnées par le docteur Carlens lu1-même, dans la revue Anesthesiology de janvier 1953, la sonde Carlens est notre premier choix comme technique d'intubation. A date, elle a été utılısée dans plus de cinq cents cas : résections pulmonarres, décortications, thoracoplasties.

Nous employons aussı le bloqueur Thompson, une sonde endo-bronchique ou une simple sonde endo-trachéale. Dans quelques cas limites au point de vue respiratoire, nous avons aussı employé le "Cocktallytique" de Huguenard et Laborit associé au non à l'anesthésie locale ou régionale

Au cours de l'opération, le cardiothacoscope ett l'oxymètre sont des aides précieux pour l'anesthésıste dans la survellance de son patıent En présence d'arrêt cardiaque, l'anesthésiste doit pourvoir à l'oxygénation par tous les moyens possibles Enfin, il doit maintenır le volume sanguin en remplaçant adéquatement le sang perdu

III Pour l'anesthésiste, la période post-opératorre est aussi importante que l'opération elle-même Dans les premières heures de la réanımation, il demeure avec son patıent aussi longtemps que l'état de ce dernıer l'exige

Par la suite, de concert avec le chirurgıen, il prend charge du service de l'oxygénation, de la transfusion, de l'aérosolthérapie et de la physiothérapie.

En conclusion, nous pouvons dire que les succès actuels de la chirurgie thoracique sont dans une grande mesure dus aux progrès de l'anesthésie thoracique moderne.

\section{REFERENCES}

Albert, Solomon N Anaesthesia for Pulmonary Partial Resection Anesth \& Analg 31 (1952)

Arden, G P, Mandow, G A \& Stoneham, F J R Plasmosan in the Prevention and Treatment of Shock Lancet, May 19, 1951

BeEcher. Some Problems of Acid-Base Equilibrium during Anaesthesia with particular references to Thoracic Surgery Anesth et Analg 9, supp 2 (1952)

Bonica, JoHN Transtracheal Anaesthesia for Endotracheal Intubation Anesthesiology 10 (1949)

Bonica, John \& Hall, William. Endobronchial Anaesthesia for Intra-Thoracic Surgery Anesthesiology 12 (1951)

Carlens, Eric A new Flexible Double Lumen Catheter for Bronchospirometry J Thoracic Surg 78 (1949)

Cooper, B M Locum, Harvey C S, Alifan, Charles, $R$ The Control of Respiration. Anaesthesiology 2 (1950)

Curreri, A R, Gale, J W, Dickre, H A L'efficacité du Diomoran Methyl-morphinane comme analgésıque dans les cas d’opérations thoracıques 「 Thoracic Surg July 1950.

Drtrinich, Howard Team Work in Cardiac Arrest (Editorial) Anesth \& Analg. 31 (1952).

Donald, K W Definition and Assessment of Respiratory Function Brit M J. (1953)

Engush, I C W Selective Bronchial Intubation in Anaesthesı for Thoracic Surgery Anesth \& Analg 29 (1950)

Fishen, Katherine \& Windoror, Trovis Contributions of Electrocardiography to Anaesthesia for Chest Surgery Anesthesiology 13 (1952).

Forster, S, Forster, ME \& MAYer, H Anesthésıe potentialisée en chrurgie thoracique. Semaine d hôp Pans, maı 2, 1952

Gaensler, Edward A Analysis and Critique of Pulmonary Function Studies. Bull New England $M$ Center 13 49, 61 (1951) 
Graham, Jones Tracheobronchial Aspiration J A A Nurse Anesth 20 (1952).

GréGoire, FERnand Pulmonary Function Studies. A paper read before the Fourth Conference of the McIntyre Foundation on Silicosis, held in Noranda, Quebec, 1952, January $28-30$

- - Physiological Tests in relations with Pulmonary Tuberculosis, reprinted from medical papers delivered at the 5lst Annual Meeting of the Canadran Tuberculosis Association at Toronto, Ontario, May, 1951.

Gruenwolw, Chardes \& Sword, Brian C A Review of Anaesthetic Procedure employed in 1616 Major Thoracic Operations for Pulmonary Tuberculosis Complications and Sequelae Anesthesiology 10 (1949)

Guild, Carl H Problems of Anaesthesia in Thoracic Surgery Anesthesiology 12 (1951)

Herbeau, M \& Chesneau, G Technque d'anesthésie endo-bronchique dans les lobectomies et segmentectomies pulmonaires Anesth et Analg 9 (1952).

Hellijos, C, Carder, V W, Maurer, R, Kay, R Preoperative and Postoperative Respira. tory Studies. Anesthesiology 13 (1952)

Himmelstein, Aoron \& Scheiner, Martin The Cardiothacoscope. Anesthesiology 13 (1952)

Hosler, R M Emergency Treatment of Cardiac Arrest J A A Nurse Anesth 20 (1952)

Huguenard, $\mathrm{P}$ Mise au point sur l'hubernation artficielle Cahier d'anesthésiologie, novembre 1953

- - Techniques et résultats de l'hibernation artficielle Anesth et analg, févner 1953

Karp, Mary \& Sorol, J KenNeth Intravenous Use of Alcohol in the Surgical Patuent. J A M A 146 (1951)

Laborit, H \& Huguenafi, $P$ Technique actuelle de l'hibernation artificielle Presse méd, no $68(1952)$

Lear, W V Preoperative Treatment and Premedication for Thcracic Operation Anesth \& Analg 29 (1950)

ManNi, C L'anesthésıe dans les opérations pour kystes hydratiques du poumon Anesth et analg 9 (1952)

Mokensie, W G Anaesthesia for Thoracic Surgery JA A Nurse Anesth 19 (1951)

Ottolenchi, Roberto \& Mozzoni, Piero A New Short-Acting Curansing Agent Anesth \& Analg. 31 (1952)

Ouglov, $F$ Les problèmes d'anesthésie en chirurgie pulmcnarre Anesth et analg 9 (1952)

Palomera, Enbrque Sanchez. Cardiac Resuscitation Surg, Gynec \& Obst 95 (1952)

Pierce, V, Boyan, C P, Masterson, J C Studies on Venous Pressure in Patent undergoing Major Surgical Procedures Surg, Gynec \& Obst. 96 (1953)

Pinson, K B Constant Suction in Lung Surgery Anaesthesia 7 (1952)

Saunders, Peter Management of Positive Pressure in Endobronchial Anaesthesia. Anesthesiology 10 (1949)

Scurr, C F Regional Anaesthesia for Thoracoplasty with special reference to the Use of Xylocame Anesth \& Analg 31 (1952).

Stephen, C R, Slater, H M, Johnson, A L \& Sekel, J P The Oximeter A Technical Aid for the Anaesthetust Anesthesiology 12 (1951)

Stephen, Elizabetr D $S$ Problems of Blocking in Upper Lobectomies Anesth. \& Analg. 31 (1952).

Viking, O B, Carlens, E \& Friberg, Olle Endobronchual Anaesthesia Anesthesiology 14 (1953). 